\title{
Haematopinus Infestations and Mycoplasma Infections of Water Buffalo (Bubalus bubalis) Herds in National Parks of Hungary
}

\author{
B. Egri ${ }^{1, *}$, L. Stipkovits ${ }^{2}$ and R. Piszmán ${ }^{3}$ \\ ${ }^{1}$ Department of Animal Science, Széchenyi István University, Mosonmagyaróvár Hungary \\ ${ }^{2} R T$-Europe Research Centre, Mosonmagyaróvár, Hungary \\ ${ }^{3}$ Kiskunsági Nemzeti Park, Kecskemét, Hungary
}

\begin{abstract}
The biology, epidemiology and pathology of sucking louse infestation and Mycoplasma infection of water buffalo (Bubalus bubalis) herds in Hungarian national parks were studied between 19 December 2011 and 4 May 2012. A total of 333 water buffaloes were examined in buffalo stocks of the Balaton Uplands, Fertö-Hanság and Kiskunság National Parks. The objective was to determine the prevalence and rate of sucking louse infestation and mycoplasma infection among water buffaloes. Always an area of identical size $\left(2 \mathrm{~cm}^{2}\right)$ was examined on the right or left side of the middle part of the animals' neck. A total of 3106 eggs, 10 nymphs and 105 adults of the sucking louse Haematopinus tuberculatus were identified with the help of a Conrad USB microscopic camera and a Wild-Leitz-Leica M420 photomacroscope. The data were evaluated using the Quantitative Parasitology software QP 3.0. The prevalence of mycoplasmas was determined in 20 randomly selected buffaloes of two national parks with the help of sterile nasal and vaginal transport swabs (Sarstedt). All of the 10 nasal swabs collected from buffaloes in the Balaton Uplands National Park contained Mycoplasma bovirhinis and three swab samples yielded M. bovis as well. Mycoplasma bovirhinis was cultured from 8 out of 10 swabs taken from the vagina, and three vaginal samples also yielded M. bovis. Similar results were obtained by testing samples collected from buffaloes in the Kiskunság National Park (Mórahalom). All ten nasal swab samples yielded $M$. bovirhinis. From two samples a mixture of $M$. bovirhinis and $M$. bovis was cultured. Nine out of the 10 vaginal swabs yielded $M$. bovirhinis while two showed a combined infection by $M$. bovis and $M$. bovirhinis.
\end{abstract}

Keywords: Haematopinus, sucking louse, Mycoplasma, infection, water buffalo, Hungary.

\section{INTRODUCTION}

In Hungary, the water buffalo (Bubalus bubalis) is kept for breeding and area reconstruction purposes, under extensive rearing conditions. The objective of the work reported here was to survey the sucking louse fauna of Hungarian water buffalo stocks, given that before this survey only very old data $[1,2]$ had been available on its distribution and faunal characteristics, and for example, Haematopinus tuberculatus infection of buffaloes had not been described since 1945 .

Five louse species are known to be able to infect cattle: three species of the genus Haematopinus, along with the species Linognathus vituli and Solenopotes capillatus. Haematopinus tuberculatus is a typical parasite of the domesticated Asian buffalo, which is known to infest cattle as well [3].

Throughout the world, louse infestation of ruminants is an important problem that impairs the growth and performance parameters of both beef and dairy stocks. Louse infestation has been reported to cause blood loss [4], weight reduction of as much as $25-30 \mathrm{~kg}$, diminished milk production and development of stress

*Address correspondence to this author at the Department of Animal Science, Széchenyi István University, Mosonmagyaróvár, Hungary; Tel: +36-96-566616; Fax: +36-96-566-695; E-mail: egri.borisz@sze.hu
$[3,5-8]$. The blood-sucking lice mentioned above may also be carriers of different pathogens [9].

Host animals infested with blood-sucking lice tend to keep scratching and biting their skin, thus causing surface injuries to themselves. By rubbing their body against different objects, cattle infested with lice may damage fences or trees. Skin that has been irritated by lice has a rough surface with complete loss of hair in some areas, which gives the animals an unthrifty appearance and reduces both the slaughter value and the usability of skin and hide for industrial processing [10].

In a survey conducted in Pakistan [6], the prevalence of lice was significantly $(P<0.05)$ higher in cattle than in buffaloes: 144 out of 600 randomly selected cattle (24\%) and only 113 out of 600 randomly selected buffaloes (18\%), kept under conditions identical to those of the cattle, proved to be infected. The prevalence of louse infestation in cattle has been reported by researchers from different countries [11-13] have reported varying prevalence rates of louse infestation in cattle in association with differences in the ecological, geographic and weather conditions. Animals kept in closed management systems are not exposed to direct sunlight which favours the survival of lice. When cattle are kept in open barns, houses with outdoor runs or in free range management system, 
their skin surface is directly exposed to sunlight and consequently becomes drier, which reduces the survival chances of lice and decreases the intensity of their propagation [6].

Factors determining the severity of infestation with blood-sucking lice include the animals' age and sex and also the season. Numerous studies have been conducted to investigate correlations between the distribution of lice and the age of host animals within herds. Islam [14] reported higher incidence $(65.8 \%)$ of $H$. tuberculatus infestation among one-year-old buffaloes than in the two-year-old groups. On the other hand, according to Chowdhury [15], the incidence of $H$. tuberculatus was higher in buffaloes belonging to the two- to four-year-old group (60.0\%). Rawat et al. [16] studied the prevalence of $H$. tuberculatus infestation among buffaloes in Dehradun, India, and found that $60.57 \%$ of the 373 buffaloes were infested, with the adult buffaloes showing more severe infestation than the younger animals. In contrast, Mamun et al. [17] established that the host animal's age had a significant effect $(P<0.01)$-on the severity of infestation with ectoparasites. According to their findings, buffalo calves were more susceptible $(73.7 \%)$ than young $(70.7 \%)$ or adult buffaloes $(58.52 \%)$, thus indicating that susceptibility to ectoparasites infestation decreases with increasing age. They found bloodsucking lice on a significantly higher percentage $(P<0.01)$ of female buffaloes $(85.7 \%)$ than of male buffaloes $(56.7 \%)$. Haematopinus tuberculatus was the most common louse species in both sexes. There is no definite explanation as to why buffalo cows are more commonly infested; this phenomenon is probably related to the hormonal background of the females. This was demonstrated previously, when Lloyd [18] reported that higher prolactin and progesterone levels may make animals more susceptible to different infections. In addition to these, the production stress, pregnancy and lactation also tend to 'debilitate' female animals.

Occurrences of bovine pediculosis do not show seasonal variation in countries with a warm climate. However, in the temperate zone and in colder regions the most severe infestations occur in late winter and early spring, when the weather is cold and damp and the animals have the thickest coat of hair. The coat of hair serves as a habitat and shelter for lice, and provides optimum conditions for their propagation. During the year, the highest increase in the louse population occurs when cattle or buffaloes are kept indoors for the winter. In late spring, the number of lice suddenly decreases. It than remains at a low average level during the summer months when the hair coat becomes thinner, which provides a less favourable habitat for lice, because the high temperature of the skin surface and direct exposure to sunlight reduces the intensity of their development $[10,19]$. Other authors have also observed seasonal occurrences of pediculosis, reporting that the population of sucking lice starts to grow in late winter, reaches its peak in the spring and its nadir in the summer and autumn months [20]. In India, the highest 'louse index' was found in January and the lowest in June (Rawat et al., 1992) [16]. According to the results obtained by Hussain et al. [6] (2006), the louse population reaches its highest level in February, and the environmental conditions continue to be favorable for survival and propagation of lice in March and April.

Skin temperature has also been correlated with the severity of louse infestation. Islam [14] found large numbers of lice belonging to the species $H$. tuberculatus and $H$. bispinosa during the winter season. Chowdhury [15] observed a high level of $H$. tuberculatus infestation both in summer and in winter. From November 2007 to October 2008, a total of 236 buffaloes were examined in the Kurigram district of Bangladesh and-, nearly $62 \%$ of them were found to be infested by one or multiple ectoparasite species. The highest level of infestation was observed in the winter and it,- then decreased in the summer, reaching its lowest level in the rainy seasons [17]. Haematopinus tuberculatus is known to be a vector for the species Trypanosoma evansi and Anaplasma marginale.

Mycoplasma bovis was first isolated from the milk of a mastitic cow in 1961 [21]. After the first report about bovine mastitis due to mycoplasma infection in Europe [22], a series of mastitis cases due to $M$. bovis (earlier known as $M$. agalactiae var. bovis) were reported in 1962 in the USA [21] and the pathogen was subsequently described as $M$. bovimastitidis [23], until finally it was elevated to species level as $M$. bovis [24]. Since that time, $M$. bovis infection has frequently been detected in the United States and also in most European countries [25], Canada [26], Latin America [27] and Africa [28]. This infection has been associated not only with mastitis but also with respiratory disease $[29,30]$, arthritis [31], meningitis [32], otitis [33, 34] and infertility in cattle [35], and it has been recovered from the eyes of bullocks [36] and the reproductive organs of cows [26].

In a survey conducted by the World Organization for Animal Health (Office International des Epizooties, 
(-OIE)) in over 48 countries, $M$. bovis was a major component of the calf pneumonia complex, with isolation rates of 23 to $35 \%$ [37]. In another study, serological tests for $M$. bovis gave positive results in $76 \%$ of beef cattle and in an even higher percentage of veal calves [38]. In buffaloes, mastitis associated with M. bovis was described in Egypt [9, 28, 39, 40]; however, buffaloes were found to be less susceptible than cattle [41]. In Kansas (USA), during a highmortality outbreak caused by $M$. bovis in North American bison (Bison bison) a total of 53 out of 194 animals died. There were abscesses in the lung and liver, fibrinosuppurative pleuritis, polyarthritis, and disseminated microabscesses in various organs [42]. A similar disease was reported from North Dakota (USA), where necrotic pharyngitis associated with $M$. bovis infection occurred in American bison [43].

The study presented in this paper was undertaken to obtain data on the biology, epidemiology and pathology of sucking louse infestation and Mycoplasma infection of water buffalo herds in national parks of Hungary.

\section{MATERIALS AND METHODS}

A total of 333 buffaloes were included in our study, which was conducted between December 19, 2011 and May 4, 2012. The buffaloes were selected from the stocks of three national parks, the Balaton Uplands (Zalavár), Fertö-Hanság (Hany) and Kiskunság (Kígyós, Mórahalom) National Parks.

To our knowledge, in three of the buffalo stocks in the three national parks, insecticidal treatment to prevent or control louse infestation is performed twice a year. In one herd, no ectoparasiticide treatment is used at all. In the herds included in this study, hair samples were taken only from animals infested with bloodsucking lice in which the hair was covered with louse eggs that were easily visible with the naked eye. These hair samples were consistently collected from a $2 \mathrm{~cm}^{2}$ area on the side of the middle part of the neck.

During the laboratory tests, the numbers of the different developmental stages, i.e. louse eggs (Figure 1), lice and nymphs, were determined using a Conrad USB microscope.

The sex and species of adult parasite specimens were determined with the aid of a Wild-Leitz-Leica M420 photomacroscope, in accordance with the description of Ferris [44], primarily on the basis of the paratergal plates and the so-called dermal pattern.
Since herd-level parasitic infections can be most precisely assessed using quantitative parasitological values, the Quantitative Parasitology software (QP 3.0) developed by Rózsa et al. [45] and Reiczigel et al. [46] was used during our studies.

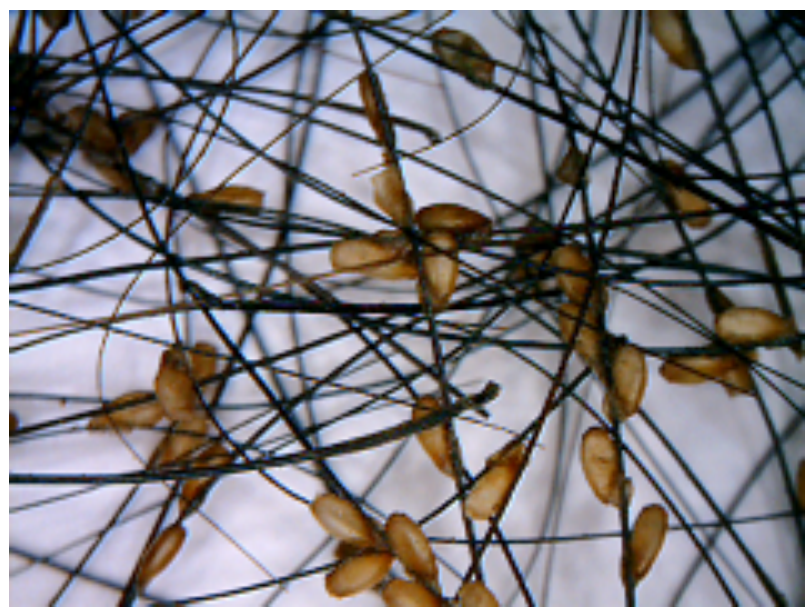

Figure 1: Eggs of Haematopinus tuberculatus glued to hairshaft of a buffalo (x16).

For mycoplasma detection, swabs from the nasal cavity and vagina were collected from 20 randomly selected adult female buffaloes in two national parks. The animals were kept free on pastures of the national parks of Balaton Uplands and Mórahalom. Nasal swab samples were cultured by means of inoculation into broth media, then plated on PPLO agar media [47] and incubated at $37{ }^{\circ} \mathrm{C}$ for 7 days. Genus determination for the isolates was performed through biochemical characterization of the purified strains. Film and spot formation was tested as described by Fabricant and Freundt [48] and Freundt et al. [49]. The isolates were identified by means of growth inhibition, capture ELISA [50] and polymerase chain reaction [51-53].

\section{RESULTS}

The evaluations reported here demonstrated that the samples collected from the 333 buffaloes contained only a single blood-sucking louse species, $H$. tuberculatus (Figure 2).

According to our observations, the female host animals and, among them, the cows showed the most severe louse infestation. Larvae of the parasite accounted for only $0.3 \%$ and adult lice represented $3.2 \%$ of all the developmental stages recovered, while $96.4 \%$ of the stages found were louse eggs. The hair samples from the bulls yielded five adult lice and 83 louse eggs, while those from the cows yielded 78 adult lice, eight larvae and 2348 louse eggs. The hair 
samples from the buffalo heifers yielded 12 adult lice, two larvae and 641 louse eggs, while from those of young males seven adult lice and 16 louse eggs were recovered. The hair samples collected from animals without an ear-tag number yielded three adult lice and 18 louse eggs. These buffaloes did not have an identification within SIRIC (the System of Individual Registration and Identification of Cattle). Most of the infested buffalo cows were in the age category of 3 to 11 years.

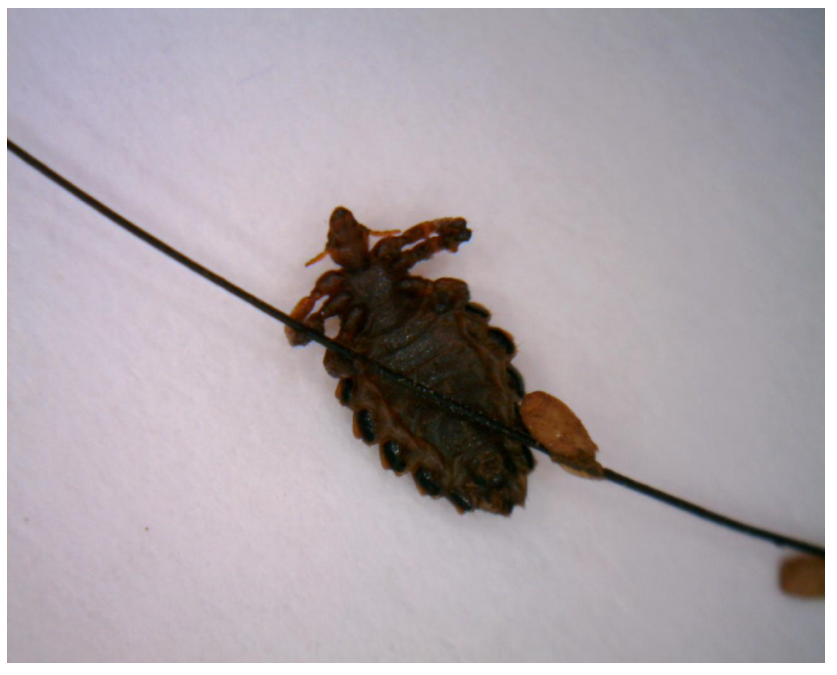

Figure 2: Haematopinus tuberculatus female (x11.7).

During the study, we collected a total of $3106 \mathrm{H}$. tuberculatus eggs, 105 adult stages of $H$. tuberculatus and $10 \mathrm{H}$. tuberculatus nymphs. The quantitative parasitological data on louse infestation in the herds studied are presented in Table 1.
The buffalo herd at Hany (Fertö-Hanság National Park) showed the most severe infestation with louse eggs, with an egg prevalence of $52.5 \%$. Given that the confidence interval for the entire population examined was best characterized by the confidence interval of prevalence, this value was $0.2102-0.3304$ for the entire study population, while for the most severely infested herd kept at Hany, it varied within wider ranges, i.e. between 0.3792 and 0.6651 . Both the median intensity (15.0) and its confidence interval (5-23) were the highest in the herd kept at Hany and, exceeded the corresponding values of the entire study population (12; 8-22). The discrepancy index (D) showed a linear correlation with the distribution according to Crofton (1971), i.e. with the fact that only a low number of parasites are usually found on many hosts. In our samples, the lowest $D$ value was found in the most severely infested herd kept at Hany $(D=0.768)$. Even the $D$ value of the total sample $(D=0.896)$ was higher than that, thus proving that the distribution of louse eggs was less aggregated in the most severely infested herd. All these statements proved to be true for louse infestation as well [54].

The mycoplasma infection of buffalo herds living in Hungary was studied in two areas, in the Balaton Uplands National Park and at Mórahalom. In both herds, samples were collected from randomly selected female animals. All of the 10 nasal swabs collected from buffaloes in the Balaton Uplands National Park contained Mycoplasma bovirhinis and three swab samples yielded $M$. bovis as well. Mycoplasma bovirhinis was cultured from 8 out of 10 swabs taken

Table 1: Quantitative Parasitological Data on Haematopinus tuberculatus Infestation in the Buffalo Herds Studied

\begin{tabular}{|c|c|c|c|}
\hline & Eggs & Nymphs & Lice \\
\hline Total number of buffaloes examined & 333 & 333 & 333 \\
\hline Number of infested buffaloes & 98 & 8 & 46 \\
\hline Prevalence (\%) & 29.4 & 2.4 & 13.8 \\
\hline Confidence limits for the prevalence $(P=0.99)$ & $0.2333-0.3628$ & $0.0077-0.055$ & $0.0945-0.1939$ \\
\hline Mean intensity & 98.0 & 8.00 & 46.0 \\
\hline Confidence limits for the mean abundance & $\begin{array}{c}(P=0.95) \\
24.13-33.50\end{array}$ & $\begin{array}{l}(P=0.99) \\
0.05-0.38\end{array}$ & $\begin{array}{l}(P=0.99) \\
4.14-8.70\end{array}$ \\
\hline Median intensity & 98.0 & 8.0 & 46.0 \\
\hline Confidence limits for median intensity & $\begin{array}{c}(P=0.99) \\
98-98\end{array}$ & $\begin{array}{c}(P=0.99) \\
8-8\end{array}$ & $\begin{array}{c}(P=0.95) \\
46-46\end{array}$ \\
\hline Mean abundance of sample & 28.84 & 0.19 & 6.35 \\
\hline Minimum intensity & 1 & 1 & 1 \\
\hline Maximum intensity & 384 & 2 & 8 \\
\hline
\end{tabular}


from the vagina, and three vaginal samples yielded $M$. bovis as well. Similar results were obtained by testing samples collected from buffaloes in the Kiskunság National Park (Mórahalom). All ten nasal swab samples yielded $M$. bovirhinis. From two samples a mixture of $M$. bovirhinis and $M$. bovis (Figure 3) was cultured. Nine out of the 10 vaginal swabs yielded $M$. bovirhinis while two showed combined infection by $M$. bovis and M. bovirhinis.

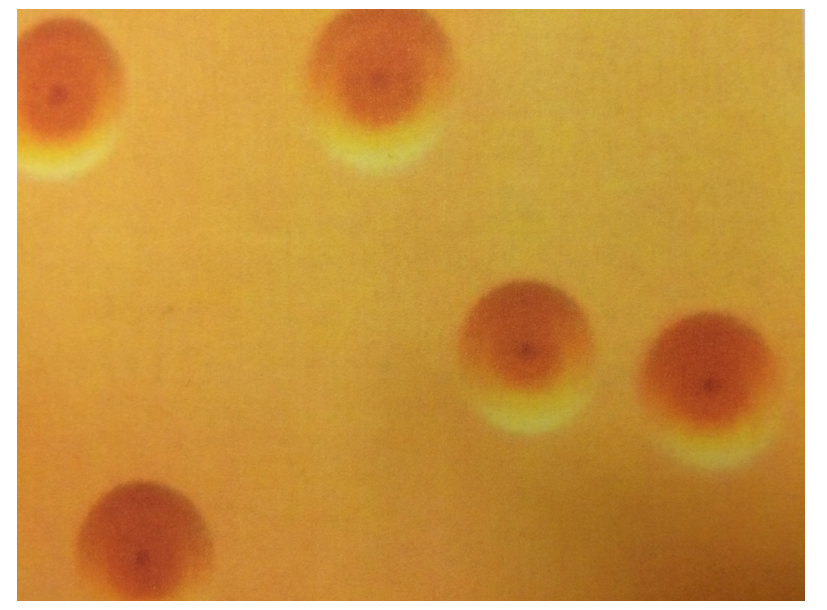

Figure 3: Mycoplasma bovis isolated from a buffalo $121 \times 116$ $\mathrm{mm}(96 \times 98 \mathrm{DPI})$.

\section{DISCUSSION}

According to Rózsa (oral communication), the species $H$. tuberculatus had not been described in Hungary since 1945, and thus the demonstration of its occurrence on buffaloes can be considered to be a new scientific fact.

Islam [14] reported that the incidence of pediculosis among buffaloes was most common in the one-yearold age category, which is at variance with our findings, since we could not demonstrate louse infestation in buffalo calves. Chowdhury [15] found $H$. tuberculatus in $60 \%$ of two to four-year-old buffaloes, which is also inconsistent with the findings of the present study, in which the majority of the louse-infested buffaloes belonged to the age category between 3 and 11 years. Rawat et al. [16] reported a $60.57 \%$ louse infestation rate among 373 buffaloes examined, with pediculosis more severely affecting the adult animals. This finding is consistent with the results from our analyses. Mamun et al. [17] observed that susceptibility to infection decreased with the advancement of age; however, this was not supported by the findings of the present study.

In their above-cited study, Mamun et al. [17] found a much higher incidence of $H$. tuberculatus infestation in female than in male buffaloes. This statement is consistent with our own findings, given that in the buffalo herd of Kígyós, the ratio of females to young males was 14:8 among the infested animals. Since young males do not have a cyclical sexual hormone production, conception and milk production did not occur in their case. As a result, we can agree with the statement of Lloyd [18], i.e. that higher prolactin and progesterone levels may make animals individually more susceptible to different infections (and thus also to louse infestation), and that 'production stress', pregnancy and lactation may compromise the resistance of female animals.

M. bovirhinis is not considered to be a pathogenic species. However, $M$. bovis is regarded as an important pathogen and it has been reported to cause significant mortality in young bovine calves in Hungary due to severe pneumonia and arthritis [31]. M. bovis has been implicated in reproductive disorders (such as infertility and abortion) as well in severe mastitis in cows [35].

\section{CONCLUSIONS}

This is the first published paper on mycoplasma infection among buffaloes in Hungary. It provides important information about the presence of $M$. bovis in buffaloes. Parasitic invasion might play a role as a vector in the intensive spreading of mycoplasma infection among buffaloes. The results obtained in this study draw attention to the importance of preventing the spread of mycoplasma infection and implementing control programs against parasitoses of animals.

\section{ACKNOWLEDGEMENTS}

The authors thank Prof. Dr. Lajos Rózsa and the veterinarians of the national parks participating in the study, Dr. Tamás Ásványi, Dr. Tibor Horváth, Dr. Tibor Kovács and Dr. Gábor Zajzon, for their help provided during the study.

\section{REFERENCES}

[1] Csiki E. A bivalytetüröl [About the buffalo louse]. Rovartani Lapok 1905; 12: 209.

[2] Dudich E. Adatok hazánk Anoplura-faunájához [Data on the Anoplura fauna of Hungary]. Rovartani Lapok 1923; 26: 5961.

[3] Nickel WE. The economical importance of cattle lice in Australia: Advances in systemic control by pour-on method. Vet Med Rev 1971; 2/3: 392-404.

[4] Hussain MA, Khan MN, Iqbal Z, Sajid MS, Arshad M. Bovine pediculosis: prevalence and chemotherapeutic control in Pakistan. Livest Res Rural Develop 2006; 18: 10-17. 
[5] Scharff DK. An investigation of the cattle louse problem. J Econ Entomol 1962; 55: 684-688.

http://dx.doi.org/10.1093/jee/55.5.684

[6] Fadok VA. Parasitic skin diseases of large animals. Vet Clin North Am Large Anim Pract 1984; 6: 3-26.

[7] Gibney VJ, Campbell JB, Boxler DJ, Clanton DC, Deutscher $\mathrm{GH}$. Effects of various infestation levels of cattle lice (Mallophaga: Trichodectidae and Anoplura: Haematopinidae) on feed efficiency and weight gains of beef heifers. J Econ Entomol 1985; 78: 1304-1307.

http://dx.doi.org/10.1093/jee/78.6.1304

[8] Loomis EC. Ectoparasites of cattle. Vet Clin North Am 1986; 2: 299-321. http://dx.doi.org/10.1016/s0749-0720(15)31240-8

[9] Eissa SI. Some studies on Mycoplasma mastitis in cattle and buffalos in Egypt. PhD thesis, Alexandria University, Alexandria, Egypt 1986.

[10] Walker B. Cattle lice. Prime Fact 2007; 337: 1-4.

[11] Topgu A. Lice (Anoplura and Mallophaga) species on cattle in the Nigde region. Veteriner Fakultesi Dergisi, Ankara Universitesi 1999; 16: 51-55.

[12] Colwell DD, Clymer B, Booker CW, Guichon PT, Jim GK, Schunicht OC, Wildman BK. Prevalence of sucking and chewing lice on cattle entering feedlots in southern Alberta. Can Vet J 2001; 42: 281-285.

[13] Nafstad $O$, Grřnstřl $H$. Eradication of lice in cattle. Acta Vet Scand 2001; 42: 81-89. http://dx.doi.org/10.1186/1751-0147-42-81

[14] Islam FMS. Incidence of parasites of buffaloes in some areas of Bangladesh. MSc thesis, Department of Parasitology, Bangladesh Agricultural University, Mymensingh, Bangladesh 1989.

[15] Chowdhury MWH. External parasites of buffaloes in Mymensingh district. MSc thesis, Department of Parasitology, Faculty of Veterinary Science, Bangladesh Agricultural University, Mymensingh, Bangladesh 1992.

[16] Rawat BS, Trivedi MC, Saxena AK, Kumar A. Incidence of phthirapteran infestation upon the buffaloes of Dehradun (India). Angew Parasitol 1992; 33: 17-22.

[17] Mamun MAA, Begum N, Shahadat HM, Mondal MMH. Ectoparasites of buffaloes (Bubalus bubalis) in Kurigram district of Bangladesh. J Bangladesh Agric Univ 2010; 8: 6166.

http://dx.doi.org/10.3329/jbau.v8i1.6400

[18] Lloyd S. Effect of pregnancy and lactation upon infection. Vet Immunol Immunopathol 1983; 4: 153-176. http://dx.doi.org/10.1016/0165-2427(83)90057-0

[19] Urquhart GM, Armour J, Duncan JL, Dunn AM, Jennings FW. Veterinary Parasitology. Longman Scientific and Technical, Bath Press, Avon, UK 1996.

[20] Geden CJ, Rutz DA, Bishop DR. Cattle lice (Anoplura, Mallophaga) in New York: seasonal population changes, effects of housing type on infestations of calves and sampling efficiency. J Econ Entomol 1990; 83: 1435-1438. http://dx.doi.org/10.1093/jee/83.4.1435

[21] Hale HH, Helmboldt CF, Plastridge WN, Stula EF. Bovine mastitis caused by a Mycoplasma species. Cornell Vet 1962; 52: 582-591.

[22] Davidson I, Stuart P. Bovine mastitis caused by a mycoplasma. Vet Rec 1960; 72: 766.

[23] Jain NC, Jasper DE, Dellinger JD. Cultural characters and serological relationships of some mycoplasmas isolated from bovine sources. J Gen Microbiol 1967; 49: 401-410. http://dx.doi.org/10.1099/00221287-49-3-401

[24] Askaa A, Ernř H. Elevation of Mycoplasma agalactiae subsp. bovis to species rank: Mycoplasma bovis (Hale et al.) comb. nov. Int J Sys Bact 1976; 26: 323-325.

http://dx.doi.org/10.1099/00207713-26-3-323
Pfützner H, Bathke W, Schimmel D. Studies of bovine mycoplasma mastitis. 1. Review of literature on the occurrence of bovine mastitis with Mycoplasma involvement. Arch Exp Veterinarmed 1979; 33: 411-418.

[26] Langford EV. Mycoplasma species recovered from the reproductive tracts of western Canadian cows. Can J Comp Med 1975; 39: 133-138.

[27] Jasper DE. Bovine mycoplasmal mastitis. Adv Vet Sci Comp Med 1981; 25: 121-159.

[28] El-Ebeedy AA, Gad AS, Mostafa A, Amal Rashwan, El-Ahl SS, Ismail S, Allam NM. Isolation of Mycoplasma bovis from an outbreak of bovine mastitis in Egypt. J Egypt Vet Med Ass 1985; 45: 247-253.

[29] Ball HJ, Finlay D, Reilly GAC. Detection of Mycoplasma bovis in pneumonic calf lungs and nasal swabs. Vet Rec 1994a; 135: 531-532. http://dx.doi.org/10.1136/vr.135.22.531

[30] Maunsell FP, Woolums AR, Francoz D, Rosenbusch RF, Step DL, Wilson DJ, Janzen ED. Mycoplasma bovis infection in cattle. J Vet Intern Med 2011; 25: 772-783.

http://dx.doi.org/10.1111/j.1939-1676.2011.0750.x

[31] Stipkovits L, Ripley PH, Varga J, Pálfi V. Use of valnemulin in the control of Mycoplasma bovis infection under field conditions. Vet Rec 2001; 148: 399-402. http://dx.doi.org/10.1136/vr.148.13.399

[32] Stipkovits L, Rády M, Glávits R. Mycoplasma arthritis and meningitis in calves. Acta Vet Hung 1993; 41: 73-88.

[33] Walz PH, Mullaney TP, Render JA, Walker RD, Mosser T, Baker JC. Otitis media in preweaned Holstein dairy calves in Michigan due to Mycoplasma bovis. J Vet Diagn Invest 1997; 9: 250-254. http://dx.doi.org/10.1177/104063879700900305

[34] Lamm GC, Munson L, Thurmond MC, Barr BC, George LW. Mycoplasma otitis in California calves. J Vet Diagn Invest 2004; 16: 397-402.

http://dx.doi.org/10.1177/104063870401600505

[35] Kissi B, Juhász S, Stipkovits L. Effect of mycoplasma contamination of bull semen on fertilization. Acta Vet Hung 1985; 33: 107-117.

[36] Kirby FD, Nicholas RAJ. Isolation of Mycoplasma bovis from bullocks' eyes. Vet Rec 1996; 138: 552.

[37] Nicholas RAJ, Ayling RD. Mycoplasma bovis: disease, diagnosis, and control. Res Vet Sci 2003; 74: 105-112. http://dx.doi.org/10.1016/S0034-5288(02)00155-8

[38] Gabinaitiene A, Siugzdaite J, Zilinskas H. Laboratory diagnosis of mycoplasma infection in young cattle. Pol J Vet Sci 2011; 149: 87-93. http://dx.doi.org/10.2478/v10181-011-0013-z

[39] Marouf SA, Mohamed KF, El-Jakee J. Detection of Mycoplasma bovis and Mycoplasma bovigenitalium in cattle and buffalo in Egypt using dot ELISA and PCR with antimicrobial trials. Eur J Biol Sci 2011; 3: 1-8.

[40] Mohamed AAE, Wahba AKA, Faisal RASR, Yousreya HM. Some bacteriological and biochemical studies on subclinical mastitis in buffaloes. New York Sci J 2013; 6: 71-77.

[41] Saleh IA. Studies on milk production of buffalos. PhD thesis, Faculty of Agriculture, Mansoura University, Mansoura City, Egypt 2005.

[42] Janardhan KS, Hays M, Dyer N, Oberst RD, Debey BM. Mycoplasma bovis outbreak in a herd of North American bison (Bison bison). J Vet Diagn Invest 2010; 22: 797-801. http://dx.doi.org/10.1177/104063871002200528

[43] Dyer N, Register KB, Miskimins B, Newell T. Necrotic pharyngitis associated with Mycoplasma bovis infection in American bison (Bison bison). J Vet Diagn Invest 2013; 25: 301-303.

http://dx.doi.org/10.1177/1040638713478815 
[44] Ferris GF. Contributions toward a monograph of the sucking lice. Stanford University Publications, Biological Sciences, Stanford University, Stanford, CA, USA 1933; Vol. II(6): pp. 455-460.

[45] Rózsa L, Reiczigel J, Majoros G. Quantifying parasites in samples of hosts. J Parasitol 2000; 86: 228-232.

http://dx.doi.org/10.1645/0022-

3395(2000)086[0228:QPISOH]2.0.CO;2

[46] Reiczigel J, Abonyi-Tóth Zs, Singer J. An exact confidence set for two binomal proportions and exact unconditional confidence intervals for the difference ang ratio of proportions. Comput Stat Data An 2008; 52: 5046-5053. Updated: 2 January 2010, Budapest, Hungary, J. Reiczigel and L. Rózsa.

[47] Ernř H, Stipkovits L. Bovine mycoplasmas: Cultural and biochemical studies. Acta Vet Scand 1973; 14: 450-463.

[48] Fabricant J, Freundt EA. Importance of extension and standardization of laboratory tests for the identification and classification of mycoplasmas. Ann NY Acad Sci 1967; 143: 50-58. http://dx.doi.org/10.1111/j.1749-6632.1967.tb27643.x

[49] Freundt EA, Anderson BE, Ernř H, Kunze M, Black FT. The sensitivity of Mycoplasmatales to sodium-polyanethol- sulfonate and digitonin. Zentralbl Bakteriol Orig A 1973; 225: 104-112.

[50] Ball HJ, Mackie DP, Finlay D, Gunn J, McFarland EA, Reilly GAC, Pollock D. An antigen capture ELISA for the detection of Mycoplasma bovis in milk. Irish Vet J 1994b; 47: 45-52.

[51] Stipkovits L, Ripley PH, Tenk M, Glávits R, Molnár T, Fodor $\mathrm{L}$. The efficacy of valnemulin (Econor) in the control of disease caused by experimental infection of calves with Mycoplasma bovis. Res Vet Sci 2005; 78: 207-215. http://dx.doi.org/10.1016/j.rvsc.2004.09.005

[52] Königsson MH, Bölske G, Johansson KE. Intraspecific variation in the 16S rRNA gene sequences of Mycoplasma agalactiae and Mycoplasma bovis strains. Vet Microbiol 2002; 85: 209-220. http://dx.doi.org/10.1016/S0378-1135(01)00517-X

[53] Tenk M, Bálint Á, Stipkovits L, Bíró J, Dencső L. Detection of Mycoplasmabovis with an improved PCR assay. Acta Vet Hung 2006; 54: 427-435. http://dx.doi.org/10.1556/AVet.54.2006.4.1

[54] Egri B, Piszmán R. Haematopinus tuberculatus fertőzöttség elöfordulása bivalyállományokban [Occurrence of Haematopinus tuberculatus infection in buffalo stocks]. Magyar Állatorvosok Lapja 2014; 136: 59-64. 